\title{
Leafy Spurge Control and Improved Forage Produc- tion with Herbicides
}

\author{
R. G. LYM AND C. G. MESSERSMITH
}

\author{
Abstract
}

An experiment to evaluate 59 long-term leafy spurge (Euphorbia esula L.) management alternatives with resulting forage production was established at 4 sites in North Dakota in 1980. The herbicides applied included 2,4-D [(2,4-dichlorophenoxy)acetic acid], dicamba (3,6-dichloro-2-methoxybenzoic acid), and picloram (4-amino-3,5,6-trichloro-2-pyridinecarboxylic acid). Picloram was applied as the liquid spray, granules or using a roller or pipe-wick reduced volume applicator. All original treatments, applied in 1980 reduced leafy spurge density $65 \%$ or more but required retreatments in 1981 and 1982 to maintain good control. Picloram sprayed at $2.2 \mathrm{~kg} / \mathrm{ha}$ followed by a herbicide retreatment provided the best leafy spurge control at $84 \%$ after 3 years, but resulted in only intermediate annual forage production. Picloram roller applied provided $84 \%$ initial leafy spurge control and increased forage production an average of $28 \%$, but control declined rapidly without retreatment. Picloram pipe-wick applied gave poor leafy spurge control and no increase in forage production. The most cost effective treatments for both leafy spurge control and high forage production were annual applications of picloram at $0.28 \mathrm{~kg} / \mathrm{ha}$ or picloram plus $2,4-D$ at 0.28 plus $1.1 . \mathrm{kg} / \mathrm{ha}$. These treatments increased annual forage production by 64 and $71 \%$, respectively, and reduced leafy spurge production by $96 \%$ compared to the untreated control. Annual application of 2,4-D did not reduce the leafy spurge density but did control the top growth long enough to allow increased forage production. Several long-term management alternatives provide a choice for leafy spurge control depending on geographical location, neighboring vegetation, and economic considerations.

Leafy spurge (Euphorbia esula L.) infests over 320,000 ha in North Dakota causing an estimated total annual loss of nearly 13 million dollars (Messersmith and Lym 1983). Loss of hay and beef cattle production is estimated at 7 million dollars annually and is due to reduced forage production from leafy spurge competition and cattle avoiding grazing in leafy spurge infested areas. Leafy spurge contains a toxic substance that causes scours and weakness in cattle and may result in death (Selleck et al. 1962).

Control of perennial weeds in pasture and rangeland with herbicides often increases forage production. Elwell (1964) found that applications of 2,4,5-T [(2,4,5-trichlorophenoxy)acetic acid], silvex [2-(2,4,5-trichlorophenoxy)propanoic acid], or 2,4-D [(2,4dichlorophenoxy)acetic acid] at rates which provided at least $50 \%$ oak brush (Quercus spp.) control increased production of native grasses an average of $2,362 \mathrm{~kg} /$ ha in Oklahoma. In Arizona, native perennial grasses produced nearly 3 times more herbage per hectare than the control 1 year following treatment with 2,4,5-T at 0.84 $\mathrm{kg} / \mathrm{ha}$ to control velvet mesquite [Prosopis juliflora var. velutina (Woot.) Sarge.] (Cable and Tschirley 1961). Five years following treatment with $2,4,5-\mathrm{T}$ at $4.8 \mathrm{~kg}$ / ha for brush control in Missouri, total herbage yield was $12,300 \mathrm{~kg} /$ ha greater than control areas (Ehrenreich and Crosby 1960). In North Dakota, forage production was increased $23 \%$ following annual application of $2,4-\mathrm{D}$ at

\footnotetext{
Authors are assistant professor and professor of Agronomy. North Dakota State University. Fargo 58105

This article is published with the approval of the Director, Agricultural Experiment Station, North Dakota State University, as Journal Article No. 1399. Cooperative investigation by North Dakota Agr. Exp. Sta. and the U.S. Dep. Agr., Agr., Res. Serv.

Manuscript accepted January 28, 1985.
}

$1.1 \mathrm{~kg} /$ ha to control broadleaf weeds in rangeland (Mitich 1965).

However, increased forage production is not always large or rapid following herbicide application in rangeland. Robertson (1969) found that crested wheatgrass (Agropyron desertorum Roemer and Schultes) production was less than the check 1 year following 2,4-D application for big sagebrush (Artemisia tridentata Nutt.) control and no significant increase occurred until the third year after treatment. Prickly pear (Opuntia polyacantha Haw.) removal did not increase blue grama [Bouteloua gracilis (H.B.K.) Lag. ex. Steud] yield but made forage available to cattle (Bement 1968). Yields of perennial grass were not increased until at least $30 \%$ control of mesquite [Prosopis juliflora (Swartz) DC.] was maintained over several years in New Mexico (Herbel et al. 1983). However, once control is achieved, increased forage production can last as long as 20 years (Cable 1976).

Herbicides generally used for leafy spurge control include dicamba (3,6-dichloro-2-methoxybenzoic acid), picloram (4-amino3,5,6-trichloro-2-pyridinecarboxylic acid) and 2,4-D. The high rates of dicamba and picloram needed for long term leafy spurge control make these herbicides uneconomical for large areas in pasture and rangeland, and 2,4-D provides only short term control of shoots (Lym and Messersmith 1983).

Herbicide treatments that provide satisfactory leafy spurge control when applied either with low volume applicators or sprayed annually at below maximum use rates would be economical alternatives to high rate treatments and also would reduce the ecological risk associated with herbicide residues in the environment. The purpose of this study was to evaluate leafy spurge management alternatives with herbicides for leafy spurge control and forage production. Herbicides were evaluated as singular or repetitive treatments either spray applied or with reduced volume applicators.

\section{Materials and Methods}

An experiment to evaluate long term leafy spurge management alternatives with herbicides and resulting forage production was established at 4 sites in North Dakota in 1980. The sites included a bluegrass pasture near Sheldon, an exclosure area on the Sheyenne National Grasslands near McLeod, and 2 sites on a federal game management area near Valley City. The main population of grasses was several bluegrasses (Poa spp.) with occasional crested wheatgrass, western wheatgrass (Agropyron smithii Rydb.). smooth brome (Bromus inermis Leyss.), and big bluestem (Andropogon gerardii Vitman). All sites had at least an $80 \%$ ground cover of leafy spurge and were sparsely infested with other perennial plants like western snowberry (Symphoricarpos occidentalis Hook.) and Arkansas rose (Rosa arkansana Porter).

The herbicides included 2,4-D dimethylamine, dicamba, picloram liquid (2S), picloram $2 \%$ a.e. granules $(2 \mathrm{G})$, and picloram $2 \mathrm{~S}$ applied using a roller or pipe-wick reduced volume applicator. The conventional sprayed treatments were applied using a tractormounted sprayer delivering $75 \mathrm{~L} /$ ha water at $240 \mathrm{kPa}$. A granular applicator was used to apply the picloram $2 \mathrm{G}$ formulation. The primary component of the roller applicator was a $20 \mathrm{~cm}$ diameter pipe covered with a $1.2 \mathrm{~cm}$ thick carpet (Messersmith and Lym 1985). The carpet was uniformly treated with herbicide applied through a plastic pipe located above the roller. The roller rotated counter-clock wise at approximately $50 \mathrm{rpm}$, and the ground speed 
of the applicator was $4.8 \mathrm{~km} / \mathrm{h}$. The pipe-wick consisted of 2 parallel wick bars $2.1 \mathrm{~m}$ long and $0.3 \mathrm{~m}$ apart, each constructed from $1.9 \mathrm{~cm}$ PVC pipe with $0.3-\mathrm{cm}$ holes drilled every $5 \mathrm{~cm}$ and covered with polyfoam and canvas (50\% cotton-50\% polyester) (Messersmith and Lym 1981a). Liquid in a storage tank flowed into the wicks as the canvas contacted plant stems with flow rate dependent on weed density. The roller and pipe-wick applicator height was adjusted to treat the top one-half of the tallest leafy spurge stems. Solution concentration on the roller was picloram at $30 \mathrm{~g} \mathrm{ae} / \mathrm{L}$; this is the same solution concentration as picloram at 2.2 $\mathrm{kg} /$ ha sprayed at $75 \mathrm{~L} / \mathrm{ha}$. The solution concentration was increased for the pipe-wick applicator to picloram at $60 \mathrm{~g} \mathrm{ae} / \mathrm{L}$. since the pipe-wick applied about half the total volume per hectare as the roller applicator. The roller and wick generally app!y 50 and $75 \%$, respectively, less picloram than spray treatments of $2.2 \mathrm{~kg} / \mathrm{ha}$ in $80 \%$ or greater cover of leafy spurge (Lym and Messersmith 1980). The additive in the roller and pipe-wick treatments was an oil concentrate $(83 \%$ paraffin based petroleum oil $+15 \%$ emulsifier) at $5 \%(\mathrm{v} / \mathrm{v})$.

The experiment was established in June 1980 with 2 replications at each of the 4 sites. The design was a split plot with a factorial arrangement of treatments. The whole plots treated in June 1980 were 4.6 by $46 \mathrm{~m}$ and consisted of 10 initial alternatives ranging from no treatment to comparatively inexpensive treatments of $\$ 10 /$ ha to expensive herbicide treatments of $\$ 160 /$ ha or more (Table 1). The 10 initial treatments applied to the whole plots included an untreated control, 2,4-D at $2.2 \mathrm{~kg} / \mathrm{ha}$, picloram $2 \mathrm{G}$ and $2 \mathrm{~S}$ at 1.1 and $2.2 \mathrm{~kg} / \mathrm{ha}$, and roller and pipe-wick application of picloram alone and picloram plus $5 \%$ oil concentrate. Each whole plot was divided into six 2.3 by $15.3-\mathrm{m}$ subplots in June 1981 , and retreatment alternatives were randomly applied within each whole plot. The six follow-up treatments included no retreatment, $2,4-\mathrm{D}$ at $1.1 \mathrm{~kg} / \mathrm{ha}$, dicamba at 1.1 and $2.2 \mathrm{~kg} / \mathrm{ha}$, picloram $2 \mathrm{~S}$ at $0.28 \mathrm{~kg} / \mathrm{ha}$, and picloram $2 \mathrm{~S}$ plus $2,4-\mathrm{D}$ at 0.28 plus $1.1 \mathrm{~kg} / \mathrm{ha}$. The retreatments ranged in cost from $\$ 5$ to $\$ 50 / \mathrm{ha} / \mathrm{yr}$ for 2,4-D and dicamba at $2.2 \mathrm{~kg} /$ ha, respectively. Each subplot received an identical retreatment in June of 1982 and 1983. Leafy spurge control was evaluated between June 10 and 25 in 1981, 1982 , and 1983, and was based on visual estimates of percent leafy spurge density reduction as compared to the untreated control with $0 \%$ being no change in the number of stems and $100 \%$ being complete absence of leafy spurge stems. Retreatments were applied immediately after leafy spurge control evaluations had been made each year.
Forage yield was determined in July 1981, 1982, and 1983 by harvesting 0.9 by $6 \mathrm{~m}$ in each plot with a rotary mower. Three 0.2 by $0.3-\mathrm{m}$ samples also were taken by hand along each harvested strip and separated into forage and leafy spurge components so percent leafy spurge and forage weight in the mowed sample could be calculated. The samples were oven dried at $60^{\circ} \mathrm{C}$ and are reported with a $12 \%$ moisture content. The entire plot was mowed after harvest each year to remove dead leafy spurge stems and other plant material for improved forage measurement and maintenance of plot uniformity. The data for lcafy spurge control and forage production were analyzed using the general linear models procedure (Stat. Anal. Syst. 1982).

\section{Results and Discussion}

\section{Leafy Spurge Control}

Whole plots were treated in 1980 and visually evaluated 12 months after treatment before any retreatments were applied in 1981. The first evaluation (June 1981) represented the leafy spurge control obtained on the whole plots with the initial treatment (Table 2). Picloram $2 \mathrm{G}$ at $2.2 \mathrm{~kg} / \mathrm{ha}$, picloram $2 \mathrm{~S}$ at 1.1 and 2.2 $\mathrm{kg} / \mathrm{ha}$, or picloram roller-applied at $30 \mathrm{~g} / \mathrm{L}$ provided excellent leafy spurge control from 84 to $99 \% 12$ months after application. Picloram 2G at $1.1 \mathrm{~kg} / \mathrm{ha}$, picloram pipe-wick applied at $60 \mathrm{~g} / \mathrm{L}$ with and without oil concentrate, and picloram roller applied at 30 $\mathrm{g} / \mathrm{L}$ with oil concentrate provided leafy spurge control from 69 to $76 \%$. The $2,4-\mathrm{D}$ at $2.2 \mathrm{~kg}$ / ha provided only $25 \%$ leafy spurge control 1 ycar after application. Lcafy spurge control from the sprayed and granular treatments was consistent with the 20-year averages from these herbicides (Lym and Messersmith 1985), although the 1980 growing season was very dry, which of ten results in poor herbicide absorption and translocation. The experimental sites received below normal precipitation in 1980, ranging from $-6.27 \mathrm{~cm}$ at Valley City to $-11.46 \mathrm{~cm}$ at Sheldon (Table 3). Leafy spurge grew under dry conditions much of the growing season and was 30 to $45 \mathrm{~cm}$ shorter than normal.

The initial 1980 treatments were evaluated in 1982 and 1983 as subplots without a herbicide retreatment (Table 2). Picloram $2 \mathrm{~S}$ at $2.2 \mathrm{~kg} /$ ha maintained 75 and $76 \%$ leafy spurge control in 1982 and 1983, respectively, but all other 1980 single treatments declined to 58 and $41 \%$ control or less in 1982 and 1983, respectively. The rapid decline was not typical, especially for picloram at $2.2 \mathrm{~kg} / \mathrm{ha}$, which generally maintains leafy spurge control at $85 \%$ or better for 18 to 24 months in North Dakota (Lym and Messersmith 1983). The

Table 1. Herbicide cost for 10 original herbicide treatments applied in 1980 and five annual retreatments applied in 1981 through 1983 in 1984 dollars.

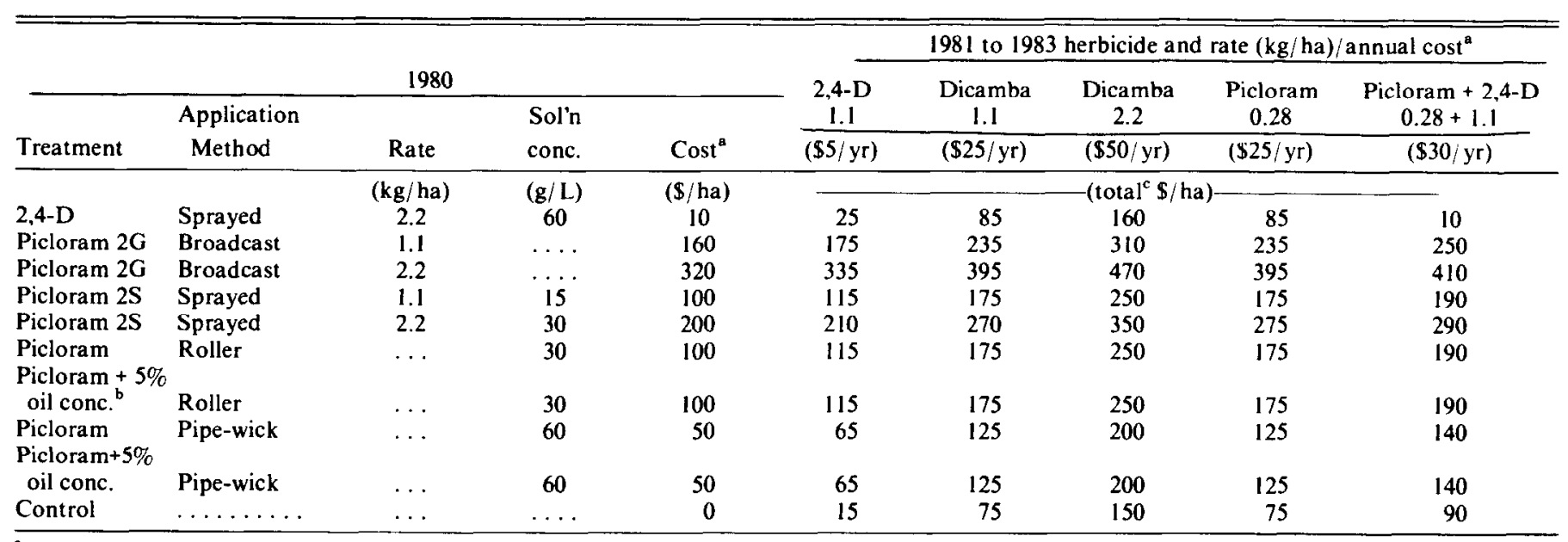

${ }^{a}$ Costs do not include application costs which vary depending on location and equipment used. Estimated herbicide cost: $2,4-\mathrm{D}=\$ 5 / \mathrm{kg}$ ai, picloram $2 \mathrm{~S}=\$ 100 / \mathrm{kg}$ ai, picloram $2 \% \mathrm{G}=\$ 160 / \mathrm{kg}$ ai, dicamba $=\$ 25 / \mathrm{kg}$ ai.

${ }^{b} 8 \%$ paraffin based petroleum oil $+15 \%$ emulsifier.

'Total cost of 1980 treatment plus 3 annual retreatments. 
Table 2. Leafy spurge control from 10 original herbicide treatments spray, roller or pipe-wick applied in June 1980 and five annual retreatments in June 1981 and 1982 averaged over four locations in North Dakota.

\begin{tabular}{|c|c|c|c|c|c|c|c|c|c|c|}
\hline \multicolumn{4}{|c|}{1980} & \multirow[b]{2}{*}{$\begin{array}{c}\text { Treated } \\
\text { in } 1980 \\
\text { only }\end{array}$} & \multicolumn{5}{|c|}{1981 and 1982 herbicide and rate $(\mathrm{kg} / \mathrm{ha})$} & \multirow[b]{2}{*}{$\begin{array}{l}\text { Retreat- } \\
\text { ment } \\
\text { mean }\end{array}$} \\
\hline \multirow[t]{2}{*}{ Treatment } & $\begin{array}{l}\text { Application } \\
\text { method }\end{array}$ & Rate & $\begin{array}{l}\text { Sol'n } \\
\text { conc. }\end{array}$ & & $\begin{array}{c}2,4-D \\
1.1\end{array}$ & $\begin{array}{c}\text { Dicamba } \\
1.1\end{array}$ & $\begin{array}{c}\text { Dicamba } \\
2.2\end{array}$ & $\begin{array}{c}\text { Picloram } \\
0.28\end{array}$ & $\begin{array}{c}\text { Picloram } \\
+2,4-\mathrm{D} \\
0.28+1.1\end{array}$ & \\
\hline & & $(\mathrm{kg} / \mathrm{ha})$ & $(g / L)$ & - & - & $-(\mathrm{P}$ & cent contro & b & 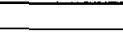 & - \\
\hline \multicolumn{11}{|c|}{ Evaluated June 198I } \\
\hline $2,4-\mathrm{D}$ & Sprayed & 2.2 & 60 & 25 & $\ldots$ & $\ldots$ & .. & $\ldots$ & $\ldots$ & $\ldots$ \\
\hline Picloram 2G & Broadcast & 1.1 & $\ldots$ & 76 & $\ldots$ & . . & $\cdots$ & $\ldots$ & $\ldots$ & $\cdots$ \\
\hline Picloram 2G & Broadcast & 2.2 & $\ldots$ & 98 & .. & .. & $\ldots$ & $\ldots$ & $\ldots$ & . . \\
\hline Picloram 2S & Sprayed & 1.1 & 15 & 97 & $\ldots$ & $\ldots$ & $\ldots$ & $\ldots$ & $\ldots$ & . . \\
\hline Picloram 2S & Sprayed & 2.2 & 30 & 99 & $\ldots$ & $\ldots$ & $\ldots$ & $\ldots$ & $\ldots$ & $\ldots$ \\
\hline Picloram & Roller & $\ldots$ & 30 & 84 & $\ldots$ & $\ldots$ & $\ldots$ & $\ldots$ & $\ldots$ & $\ldots$ \\
\hline \multicolumn{11}{|l|}{ Picloram + 5\% } \\
\hline oil conc. & Roller & $\ldots$ & 30 & 70 & $\ldots$ & $\ldots$ & $\ldots$ & $\ldots$ & $\ldots$ & $\ldots$ \\
\hline Picloram & Pipe-wick & $\ldots$ & 60 & 69 & $\ldots$ & $\ldots$ & $\ldots$ & $\ldots$ & $\ldots$ & $\ldots$ \\
\hline \multicolumn{11}{|l|}{ Picloram $+5 \%$} \\
\hline oil conc. & Pipe-wick & $\ldots$ & 60 & 71 & $\ldots$ & $\ldots$ & $\ldots$ & $\ldots$ & $\ldots$ & $\ldots$ \\
\hline $\begin{array}{l}\text { Control } \\
\quad \operatorname{LSD}(0.05)\end{array}$ & $1980=17$ & $\ldots$ & $\cdots$ & 0 & $\cdots$ & $\cdots$ & $\ldots$ & $\ldots$ & $\ldots$ & . \\
\hline \multicolumn{11}{|c|}{ Evaluated June 1982} \\
\hline $2.4-\mathrm{D}$ & Sprayed & 2.2 & 60 & 1 & 10 & 8 & 9 & 26 & 28 & 16 \\
\hline Picloram 2G & Broadcast & 1.1 & $\ldots$ & 14 & 18 & 14 & 29 & 35 & 35 & 26 \\
\hline Picloram 2G & Broadcast & 2.2 & $\ldots$ & 58 & 54 & 60 & 57 & 69 & 67 & 61 \\
\hline Picloram 2S & Sprayed & 1.1 & 15 & 43 & 39 & 42 & 51 & 46 & 52 & 46 \\
\hline Picloram 2S & Sprayed & 2.2 & 30 & 75 & 84 & 76 & 91 & 93 & 80 & 85 \\
\hline Picloram & Roller & $\ldots$ & 30 & 28 & 20 & 27 & 24 & 31 & 45 & 29 \\
\hline \multicolumn{11}{|l|}{ Picloram $+5 \%$} \\
\hline oil conc. & Roller & $\ldots$ & 30 & 26 & 24 & 24 & 28 & 36 & 41 & 31 \\
\hline Picloram & Pipe-wick & $\ldots$ & 60 & 10 & 11 & 9 & 9 & 23 & 21 & 15 \\
\hline \multicolumn{11}{|l|}{ Picloram + 5\% } \\
\hline oil conc. & Pipe-wick & $\ldots$ & 60 & 13 & 11 & 24 & 28 & 46 & 34 & 29 \\
\hline Control & $\ldots \ldots \ldots$ & $\ldots$ & $\ldots$ & 0 & 3 & 2 & 6 & 15 & 20 & 9 \\
\hline Mean & $\ldots \ldots \ldots$ & $\ldots$ & & 27 & 28 & 29 & 34 & 42 & 43 & 9 \\
\hline $\operatorname{LSD}(0.05)$ & $1980=5 ; 198$ & $1980 \times 198$ & 13 & & & & & & & \\
\hline \multicolumn{11}{|c|}{ Evaluated June 1983} \\
\hline $2,4-\mathrm{D}$ & Sprayed & 2.2 & 60 & 4 & 14 & 34 & 25 & 59 & 65 & 39 \\
\hline Picloram 2G & Broadcast & 1.1 & $\ldots$ & 10 & 17 & 9 & 44 & 59 & 75 & 41 \\
\hline Picloram 2G & Broadcast & 2.2 & $\cdots$ & 41 & 52 & 65 & 60 & 69 & 74 & 64 \\
\hline Picloram 2S & Sprayed & 1.1 & is & 39 & 53 & 50 & 72 & 52 & 66 & 59 \\
\hline Picloram 2S & Sprayed & 2.2 & 30 & 76 & 84 & 87 & 89 & 87 & 83 & 86 \\
\hline Picloram & Roller & $\ldots$ & 30 & 31 & 20 & 31 & 44 & 63 & 60 & 44 \\
\hline \multicolumn{11}{|l|}{ Picloram $+5 \%$} \\
\hline oil conc. & Roller & $\cdots$ & 30 & 21 & 31 & 34 & 53 & 63 & 71 & 50 \\
\hline Picloram & Pipe-wick & $\ldots$ & 60 & 5 & 8 & 17 & 43 & 49 & 55 & 35 \\
\hline \multicolumn{11}{|l|}{ Picloram + 5\% } \\
\hline oil conc. & Pipe-wick & $\ldots$ & 60 & 8 & 17 & 24 & 33 & 74 & 61 & 42 \\
\hline Control & $\ldots \ldots \ldots$ & $\ldots$ & $\ldots$ & 0 & 10 & 10 & 36 & 22 & 38 & 23 \\
\hline Mean & & & & 24 & 31 & 37 & 50 & 60 & 65 & \\
\hline LSD & $(0.05)$ & $1980=9 ; 19$ & $\& 1982$ & $; 1980 \times($ & $1 \& 198$ & $=22$ & & & & \\
\hline
\end{tabular}

$83 \%$ paraffin based petroleum oil $+15 \%$ emulsifier.
${ }^{6}$ Evaluations were 12 months after treatment and immediately prior to the retreatment applied for the year.

picloram $2 \mathrm{~S}$ formulation provided an average of 23 and $32 \%$ better leafy spurge control than the $2 \mathrm{G}$ formulation at 24 and 36 months following application, respectively. Picloram $2 S$ and $2 G$ generally provide similar leafy spurge control in North Dakota but the dry conditions of 1980 may have resulted in inadequate activation of the granules for leafy spurge control. Also, the dry conditions reduced plant vigor and probably caused poor absorption and translocation of foliarly applied picloram. The leafy spurge topgrowth was too short for good contact with the roller or pipe-wick applicators, resulting in poor long-term control. Leafy spurge control is enhanced when most of the topgrowth is treated as compared to treating only the upper half of most stems (Messersmith and Lym 1985).

Both retreatments in $198 \mathrm{I}$ that included picloram at $0.28 \mathrm{~kg} / \mathrm{ha}$ and dicamba at $2.2 \mathrm{~kg}$ / ha increased leafy spurge control compared
Table 3. Total precipitation and departure from normal at four experimental sites from 1980 to 1983.

\begin{tabular}{|c|c|c|c|c|c|c|}
\hline \multirow[b]{3}{*}{ Year } & \multicolumn{6}{|c|}{ Site and precipitation ${ }^{\mathrm{a}}$} \\
\hline & \multicolumn{2}{|c|}{ McLeod } & \multicolumn{2}{|c|}{ Sheldon } & \multicolumn{2}{|c|}{ Valley City ${ }^{b}$} \\
\hline & Received & Depart. & Received & Depart. & Received & Depart. \\
\hline & & & $-(\mathrm{cr}$ & & & \\
\hline 1980 & 43.26 & -6.43 & 38.38 & -11.46 & 43.16 & -6.27 \\
\hline 1981 & 58.24 & +8.61 & 59.20 & +9.37 & 44.98 & -4.46 \\
\hline 1982 & 51.46 & +1.78 & 51.30 & +1.47 & 45.38 & -4.04 \\
\hline 1983 & 46.25 & -2.64 & 43.56 & -6.27 & 44.65 & -2.10 \\
\hline
\end{tabular}

${ }^{a}$ Seventy-five percent of the annual precipitation occurs during the growing season (April to September).

${ }^{5}$ Two sites were located near Valley City. 
to no retreatment when evaluated in 1982 (Table 2). The retreatments did not maintain control at the 1981 level except 2 retreatments following picloram $2 \mathrm{~S}$ at $2.2 \mathrm{~kg} /$ ha which maintained 92 and $93 \%$ control, respectively, compared to picloram $2 \mathrm{~S}$ alone, which provided $75 \%$ leafy spurge control. I eafy spurge control with picloram roller-applied at $30 \mathrm{~g} / \mathrm{L}$ in 1980 declined from $84 \%$ in 1981 to $28 \%$ in 1982 . Leafy spurge control with picloram applied at $60 \mathrm{~g} / \mathrm{L}$ in a pipe-wick with and without oil concentrate, declined from 69 and $71 \%$ control in 1981 , respectively, to 13 and $10 \%$ control, respectively, in 1982 . None of the retreatments maintained leafy spurge control higher than $46 \%$ with any roller or pipe-wick applied original treatment. Additives with picloram roller or pipewick applied did not improve leafy spurge control. Retreatment with $2,4-\mathrm{D}$ or dicamba at $1.1 \mathrm{~kg} /$ ha did not improve leafy spurge control regardless of the original 1980 treatments.

In general, leafy spurge control from the retreatments improved in 1983 compared to 1982 (Table 2). The enhanced control probably was due both to the improved growing conditions during 1982 , which increased the susceptibility of leafy spurge to herbicide injury, and to a gradual loss of vigor in the leafy spurge plant following 3 years of annual treatment. Picloram $2 \mathrm{~S}$ at $2.2 \mathrm{~kg} / \mathrm{ha}$ was the only 1980 initial treatment without retreatment to maintain satisfactory $(76 \%)$ leafy spurge control by 1983 , and control was increased to $86 \%$ when averaged across the 5 herbicide retreatments. Leafy spurge control from picloram $2 S$ at $1.1 \mathrm{~kg} / \mathrm{ha}$ applied in 1980 had declined to $39 \%$ in 1983 , but control was increased to 72 and $66 \%$ with retreatments of dicamba at $2.2 \mathrm{~kg} / \mathrm{ha}$ or picloram plus 2,4-D at 0.28 plus $1.1 \mathrm{~kg} / \mathrm{ha}$, respectively. Picloram $2 \mathrm{G}$ at $2.2 \mathrm{~kg} /$ ha without retreatment provided only $41 \%$ leafy spurge control in 1983 , but control was $64 \%$ averaged over the 5 retreatments. Picloram $2 \mathrm{G}$ at $1.1 \mathrm{~kg} /$ ha applied in 1980 provided only $10 \%$ leafy spurge control in 1983 but control increased to $75 \%$ with 2 annual retreatments of picloram plus $2,4-\mathrm{D}$ at 0.28 plus 1.1 $\mathrm{kg} / \mathrm{ha}$.

Picloram roller or pipe-wick applied and $2,4-\mathrm{D}$ at $2.2 \mathrm{~kg} / \mathrm{ha}$ in 1980 provided $21 \%$ or less leafy spurge control in 1983 (Table 2).
Annual retreatment of picloram at $0.28 \mathrm{~kg} /$ ha or picloram plus 2,4-D at 0.28 plus $1.1 \mathrm{~kg} /$ ha over the roller and pipe-wick treatments gave an average of $62 \%$ leafy spurge control. Thus even with an annual retreatment, the roller and pipe-wick treatments did not provide long-term satisfactory leafy spurge control.

Dicamba at $2.2 \mathrm{~kg} / \mathrm{ha}$, picloram at $0.28 \mathrm{~kg} / \mathrm{ha}$, and picloram plus $2,4-\mathrm{D}$ at 0.28 plus $1.1 \mathrm{~kg} /$ ha provided 34,42 , and $43 \%$ leafy spurge control, respectively, in 1982 and 50,60 , and $65 \%$, respectively, in 1983 when averaged across all original 1980 treatments (Table 2). Dicamba or 2,4-D each at $1.1 \mathrm{~kg} /$ ha were less effective than the other retreatments, because leafy spurge top growth was prevented for only 1 to 2 months.

The best leafy spurge control after 3 years was 83 to $89 \%$ from picloram $2 \mathrm{~S}$ at $2.2 \mathrm{~kg} /$ ha followed by any retreatment. The best leafy spurge control in plots treated with picloram in a reduced volume applicator was from roller application at $30 \mathrm{~g} / \mathrm{L}$ with annual retreatments of picloram plus $2,4-\mathrm{D}$ at $0.28 \mathrm{plus} 1.1 \mathrm{~kg} / \mathrm{ha}$ at $71 \%$ and pipe-wick application at $60 \mathrm{~g} / \mathrm{L}$ with oil concentrate followed by annual retreatments of picloram at $0.28 \mathrm{~kg} /$ ha at $74 \%$. The roller applicator applied $60 \%$ less herbicide than the sprayer applicator when using similar application conditions (Messersmith and Lym 1985), so the initial treatment with a reduced volume applicator may result in an economic advantage even though the leafy spurge control was less than from a sprayed or granular treatment.

\section{Forage Production}

Forage and leafy spurge production was consistent by location and year and were combined for discussion. Forage production increased for 27 of the 59 herbicide treatments and leafy spurge production was decreased by all treatments compared to an average of 1,314 and $1,490 \mathrm{~kg} /$ ha, respectively, for the untreated control (Table 4). It was expected that leafy spurge production would be low because harvest was 3 to 4 weeks after herbicide application each year. Even when herbicides were applied only in 1980, all treatments reduced leafy spurge production compared to the untreated control.

Table 4. Mean forage and leafy spurge production following leafy spurge control with 10 original herbicide treatments applied in June 1980 and five annual retreatments applied in June 1981 through 1983 at four sites in North Dakota.

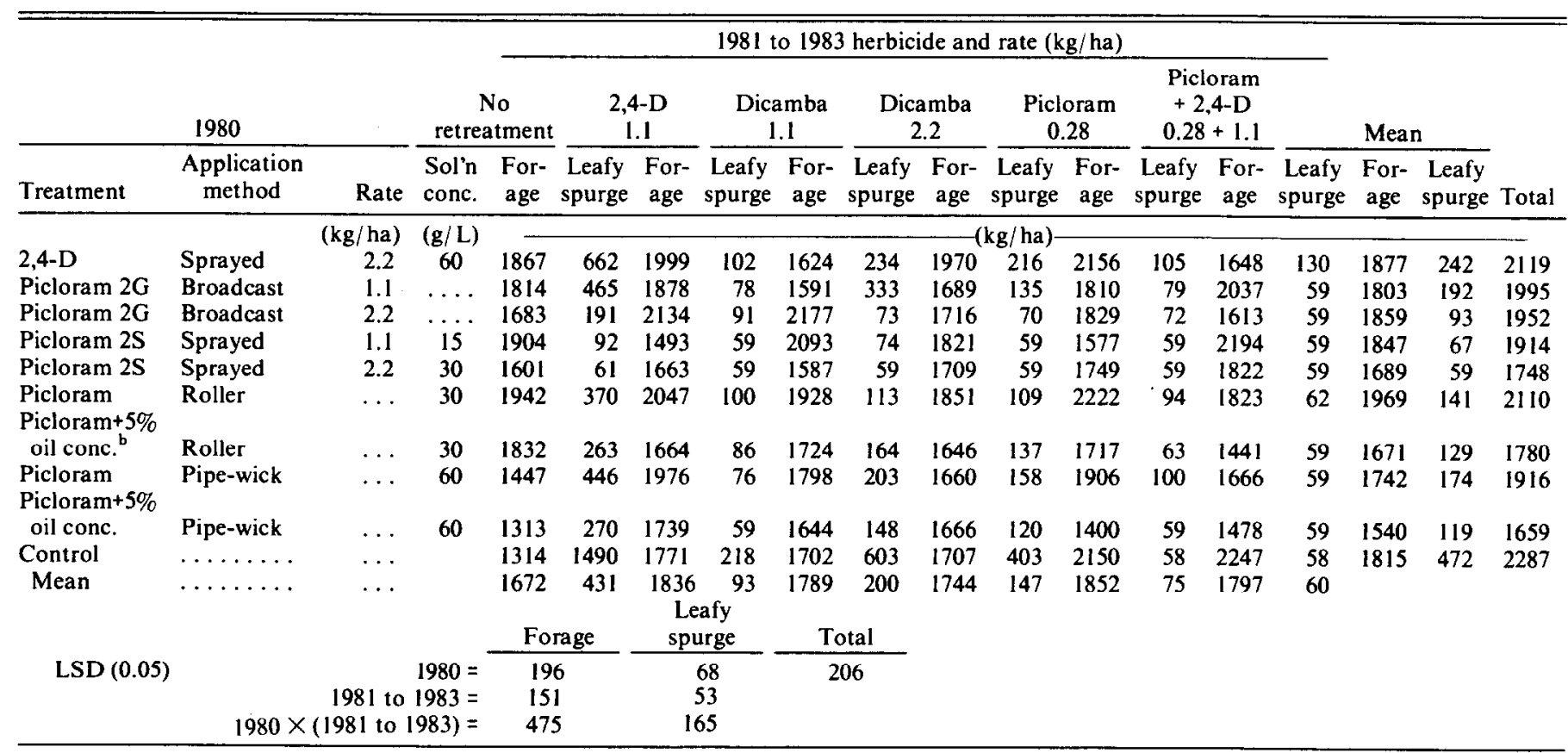

${ }^{2}$ Total = Forage plus leafy spurge production.

$83 \%$ paraffin based petroleum oil $+15 \%$ emulsifier. 
Total dry matter production for all 1980 picloram treatments was reduced compared to the control except roller application without a surfactant (Table 4). The reduction was due mainly to leafy spurge control but some treatments also reduced grass production. Total dry matter production was lowest for picloram $2 \mathrm{~S}$ at $2.2 \mathrm{~kg} / \mathrm{ha}$, and picloram roller and pipe-wick applied both with an oil concentrate. These treatments probably caused the greatest retention of picloram on grass leaves, which apparently resulted in grass injury; the forage production averaged $1,633 \mathrm{~kg} /$ ha for these treatments compared to $1,844 \mathrm{~kg} / \mathrm{ha}$ for the other five 1980 picloram treatments. Thus, all 1980 picloram treatments resulted in greater forage production than the untreated control, but grass injury prevented increases as large as for some other treatments.

Leafy spurge control does not have to be long-term to provide increased forage production. Five treatments applied in 1980 with no retreatment had an increase in forage production of $500 \mathrm{~kg} / \mathrm{ha}$ or more than the untreated control. Even a single treatment of $2,4-\mathrm{D}$ at $2.2 \mathrm{~kg} / \mathrm{ha}$ resulted in an increased forage yield despite the highest leafy spurge production among treated areas. The 4 treatments that did not significantly increase forage production, i.e., both picloram at $2.2 \mathrm{~kg} / \mathrm{ha}$ and both pipe-wick treatments, apparently can be attributed to grass injury since they had less leafy spurge production than the 2,4-D treatment. These results suggest that an irregular herbicide application program involving treatment at 2- or 3-year intervals should result in improved forage production even though the reduction of leafy spurge density will be low; however, the herbicide treatment must not cause grass injury.

The annual retreatments reduced leafy spurge yield when compared to subplots receiving only 1980 treatments, except for the three 1980 treatments that provided the best leafy spurge control when applied alone, namely picloram $2 \mathrm{G}$ at $2.2 \mathrm{~kg} / \mathrm{ha}$ and $2 \mathrm{~S}$ at 1.1 and $2.2 \mathrm{~kg} / \mathrm{ha}$ (Table 4). Picloram at $0.28 \mathrm{~kg} / \mathrm{ha}$ and picloram plus $2,4-\mathrm{D}$ at 0.28 plus $1.1 \mathrm{~kg} / \mathrm{ha}$ resulted in 2 of the highest forage yields and lowest leafy spurge yields when applied as annual treatments even with no 1980 treatment. These treatments provided 22 and 38 leafy spurge control, respectively, in 1983 (Table 2), but averaged about $2200 \mathrm{~kg} /$ ha forage production (Table 4). Thus a program that gradually reduces a leafy spurge infestation with an annual application of a relatively inexpensive herbicide combination can be most cost effective for forage production and weed control than a single expensive treatment (Table 1).

Dicamba at 1.1 and $2.2 \mathrm{~kg} / \mathrm{ha}$ applied as annual retreatments alone resulted in 1,702 and $1,707 \mathrm{~kg} /$ ha of forage and 603 and 403 $\mathrm{kg} / \mathrm{ha}$ of leafy spurge, respectively (Table 4). The 2,4-D at 1.1 $\mathrm{kg} / \mathrm{ha}$ resulted in 1,771 and $218 \mathrm{~kg} / \mathrm{ha}$ of forage and leafy spurge, respectively and is more economical than either dicamba treatment (Table 1), so it usually would be the preferred retreatment. Some grass species such as smooth brome are more susceptible to dicamba than bluegrass (McCarty and Scifres 1968, Morton et al. 1967, Vanden Born 1965) and may produce less forage after dicamba application than this study estimated. Dicamba is metabolized rapidly by bluegrass (Broadhurst et al. 1966) which may minimize injury to this species.

Herbicide treatments that provided the best leafy spurge control did not necessarily provide the highest forage production. Picloram $2 \mathrm{~S}$ at $2.2 \mathrm{~kg} /$ ha which maintained 76 to $89 \%$ leafy spurge control (Table 2) was not among the highest yielding treatments (Table 4). Picloram roller-applied at $30 \mathrm{~g} / \mathrm{L}$ alone and with retreatments provided only moderate leafy spurge control (Table 2), but was among the highest yielding of the 59 herbicide treatment combinations (Table 4). The dry conditions of 1980 may have increased plant susceptibility to picloram (Arnold and Santelmann 1966), resulting in reduced forage production. Picloram rollerapplied mostly contacted leafy spurge topgrowth, so injury that would affect forage production was minimized.

Application of $2,4-D$ at $2.2 \mathrm{~kg} / \mathrm{ha}$ in 1980 and at $1.1 \mathrm{~kg} / \mathrm{ha}$ annually thereafter provided one of the highest annual forage productions of any treatment at $1,999 \mathrm{~kg} /$ ha (Table 4), despite consistently poor leafy spurge control (Table 2 ). The 2,4-D applied to leafy spurge controls the topgrowth but has minimal control of the root system, so leafy spurge reinfests in 2 to 3 months to densities equal to or higher than the original stand (Bybee 1979, Messersmith and Lym 1981b). However, 2,4-D applied in June reduced leafy spurge competition long enough to allow increased forage production.

Picloram pipe-wick applied at $60 \mathrm{~g} / \mathrm{L}$ generally gave slight or no increase in forage production compared to the control regardless of the retreatment (Table 4). Pipe-wick treatments also were among the lowest in leafy spurge control, so they are not desirable for long-term leafy spurge management.

Higher grass density was observed in the untreated control plots than in the leafy spurge infested areas adjacent to the experiment as the experiment progressed. Thus the increase in forage production due to herbicide treatment may have been underestimated. The entire experiment was mowed immediately after harvest to provide a uniform cutting across all plots and to remove all plant material to facilitate the next year's harvest. Perhaps mowing alone allowed the grass to better compete with leafy spurge.

Several long-term management alternatives provide a choice of herbicide, application method, duration of acceptable control, and forage production in leafy spurge infested areas. If leafy spurge is in an arca that can be treated annually with relatively low application costs, then picloram at $0.28 \mathrm{~kg} / \mathrm{ha}$ or picloram plus $2,4-\mathrm{D}$ at 0.28 plus $1.1 \mathrm{~kg} /$ ha should be the most cost effective treatments when considering both leafy spurge control and forage production. The leafy spurge stand can be reduced gradually (Lym and Messersmith 1983) while the forage production is maximized. If leafy spurge is located in terrain where annual application is very expensive than picloram at $2.2 \mathrm{~kg} / \mathrm{ha}$ could be used to provide long-term leafy spurge control. Although 2,4-D is a more economical herbicide than picloram, annual 2,4-D applications will cause minimal reduction of the original infestation but should reduce spreading. The roller applicator is practical only in areas of even terrain such as abandoned crop fields or roadsides.

\section{Literature Cited}

Arnold, W.R., and P.W. Santelmann. 1966. The response of native grasses to picloram. Weeds $14: 74-76$

Bement, R.E. 1968. Plains pricklypear: Relations to grazing intensity and blue grama yield on the Central Great Plains. J. Range Manage. 21:83-86.

Broadhurst, N.A., M.L. Montgomery, and V.H. Freed. 1966. Metabolism of 2-methoxy-3,6-dichlorobenzoic acid (dicamba) by wheat and bluegrass plants. J. Agr. Food. Chem. 14:585-588.

Bybee, T.A. 1979. Factors affecting leafy spurge control including leafy spurge reestablishment, herbicide application dates, herbicide translocation, and root carbohydrates. Ph.D. Thesis. North Dakota State Univ. 80 p. Univ. Microfilms. Ann Arbor, Mich. (Diss. Abstr. 7922217).

Cable, D.R. 1976. Twenty years of changes in grass production folowing mesquite control and reseeding. J. Range Manage. 29:286-289.

Cable, D.R., and F.H. Tschirley. 1961. Response of native and introduced grasses following aerial spraying of velvet mesquite in Southern Arizona. J. Range Manage. 14:155-159.

Ehrenreich, J.H., and J.S. Crosby. 1960. Forage production in sprayed and burned areas in the Missouri Ozarks. J. Range Manage. 13:68-70.

Elwell, H.M. 1964. Oak brush control improves grazing lands. Agron. J. 56:411-415.

Herbel, C.H., W.L. Gould, W.F. Leifeste, and R.P. Gibbens. 1983. Herbicide treatment and vegetation response to treatments of mesquite in Southern New Mexico. J. Range Manage. 36:149-151.

I.ym, R.G., and C.G. Messersmith. 1980. Reduction in herbicide applied using the roller and wick applicators. Res. Rep. North Cen. Weed Control Conf. 37:56.

Lym, R.G., and C.G. Messersmith. 1983. Control of leafy spurge with herbicides. North Dakota Farm Res. 40:16-19.

Lym, R.G., and C.G. Messersmith. 1985. Leafy spurge control with herbicides in North Dakota: 20 year summary. J. Range Manage. 38: 149-154. 
McCarty, M.K., and C.J. Scifres. 1968. Smooth bromegrass response to herbicides as affected by time of application in relation to nitrogen fertilization. Weed Sci. 16:443-446.

Messersmith, C.G., and R.G. Lym. 1981a. A pipe-wick herbicide applicator for perennial weed control in pastures. Res. Rep. North Cen. Weed Control Conf. 38:36-37.

Messersmith, C.G., and R.G. Lym. 1981b. Long term management of leafy spurge in pasture and rangeland-year one. Res. Rep. North Cen. Weed Control Conf. 38:38-40.

Messersmith, C.G., and R.G. Lym. 1983. Distribution and economic impacts of leafy spurge in North Dakota. North Dakota Farm Res. 40:8-13.

Messersmith, C.G., and R.G. Lym. 1985. Roller application of picloram for leafy spurge control in pasture. Weed. Sci. 33:258-262.
Mitich, L.W. 1965. Pasture renovation with 2,4-D in North Dakota. Down to Earth 20:26-28.

Morton, H.L., E.D. Robison, and R.E. Meyer. 1967. Persistence of 2,4-D, 2,4,5-T and dicamba in range forage grasses. Weeds 15:268-271.

Robertson, J.H. 1969. Yield of crested wheatgrass following release from sagebrush competition by 2,4-D. J. Range Managc. 22:287-288.

Selleck, G.W., R.T. Coupland, and C. Frankton. 1962. Leafy spurge in Saskatchewan. Ecol. Monographs 32:1-29.

Statistical Analysis System Institute. 1982. SAS User’s Guide: Statistics. Cary, NC.

Vanden Born, W.H. 1965. The effect of dicamba and picloram on quackgrass, bromegrass and Kentucky bluegrass. Weeds 13:309-312. 